\title{
THE DIASPORA OF AFRICANS LIBERATED FROM SLAVE SHIPS IN THE NINETEENTH CENTURY*
}

\section{Daniel Domingues da Silva}

University of Missouri, Columbia

David Eltis

Emory University and University of British Columbia

\section{Philip Misevich}

St John's University, New York

\section{Olatunji Ojo}

Brock University, St Catharines

\begin{abstract}
This article uses the extensive documentation of Africans liberated from slave vessels to explore issues of identity and freedom in the nineteenth-century Atlantic world. It tracks the size, origin, and movement of the Liberated African diaspora, offers a preliminary analysis of the 'disposal' of African recaptives in societies on both sides of the Atlantic, and assesses the opportunities Liberated Africans had in shaping their postdisembarkation experiences. While nearly all Liberated Africans were pulled at least partly into the Atlantic wage economy, the article concludes that recaptive communities in Freetown and its hinterland most closely met the aspirations of the Liberated Africans themselves while the fate of recaptives settled in the Americas paralleled those who were enslaved.
\end{abstract}

\section{Key Words}

Central Africa, West Africa, diaspora, labor, quantitative sources, slavery, slavery abolition.

In the early nineteenth century, just prior to US and British abolition of the transatlantic slave trade, four million slaves lived and worked in the Americas. Distributed in almost equal measure across South America, the Caribbean, and the North American mainland, all were Africans or, if born in the Americas, descended from survivors of three centuries of slave trading on the African coast. In the six decades between the onset of formal abolition and effective suppression of the transatlantic traffic in I 867, slave ships disembarked a further 2.8 million slaves, overwhelmingly, as is well known, in Brazil and Cuba. Less well known is that after the inflows into Brazil and Cuba the third largest stream of coerced migrants in the nineteenth century $-180,969$, or around the number entering Charleston during the whole era of the trade-comprised 'recaptive captives'. Governments from Haiti in the west, Britain in the north, Argentina in the south, and colonial Mauritius

\footnotetext{
* Authors’email: dominguesd@missouri.edu, deltis@emory.edu, misevicp@stjohns.edu, and oojo@brocku.ca
} 
to the east generated this stream by directly intervening in the late transatlantic slave trade. Intervention took the form of raiding coastal barracoons on both sides of the Atlantic, detaining slave vessels at sea, or receiving survivors of wrecked slave ships. Most recaptives subsequently went through a formal registration process and became known first as 'Captured Negroes', and then, after I 822 as 'Liberated Africans' by the English and 'emancipados' by the Cubans and Brazilians. The very first of the group came ashore in Philadelphia in 1800 and the last in St Helena in 1863 .

By 1888 , a quarter-century after the last capture of a transatlantic vessel with slaves on board (the Haydee taken into St Helena in August, I863), the racial slavery that had characterized the Americas since Columbian contact was finally abolished. In the nine decades since I 800 between seven and eight million people around the Atlantic world had passed through a variety of emancipation processes, and tracking their experiences from slavery to a 'freedom', however constrained, has become a major field of scholarly endeavor. While Liberated Africans formed a small share of this total-and a scarcely larger share of the 2.8 million Africans carried across the Atlantic in the same period - they nevertheless offer a unique opportunity to explore identity and freedom in the nineteenth-century Atlantic world. All were born in Africa and provide an unrivaled picture of African responses to emancipation. By contrast, four-fifths of the millions emancipated in the Spanish mainland Americas (I8Ios), the British Caribbean (I834), the French Caribbean (I848), the Dutch Americas (I863), the United States (I865), Cuba (I886), and Brazil ( 1888 ) were native to the Americas. Moreover, for no other large group moving out of slave status is the historical record so abundant. Nearly ı००,००० individual descriptions, including African names and some indication of African language have survived and for more than half of these the records indicate what they did immediately upon leaving enslaved status.

One of the most interesting characteristics of the 180,969 Liberated Africans is the range of the terms of labor associated with their new status. Some faced conditions that differed little from enslaved people living around the world. At the other extreme might be the large numbers of Mende, Sherbro, and Temne, who absconded from Sierra Leone once they had left their slave ships to return to their home countries, or the very few who emerged as major merchants in Freetown, or who led broadly self-sufficient existences on smallholdings in the Freetown hinterland. ${ }^{\mathrm{I}}$ Between these extremes lies an unexplored treasure chest of statuses and experiences that offers insights into constructions of identities and race, labor relationships, and changing conceptions of freedom over the course of the nineteenth century. The records they left behind can be used to illuminate the process of enslavement in Africa, trans-shipment to the Americas, and the creation of new African and African-American communities. In terms of identities and culture, we might view these emancipados as surrogates for the millions of Africans who necessarily disappeared into American slavery without leaving any trace in the historical record. We are able to outline at least some of the responses of Liberated Africans to their new environments and are able to contrast such responses to the expectations of imperial and colonial authorities under whom most spent their new lives.

I See below for the significance of Sierra Leone as an administrative center in the abolition campaign. 
But to generate these insights we have to perform three preliminary tasks. The first is to track the size and direction of this subcomponent of the African diaspora. Second, we need to offer a preliminary analysis of their 'Disposal' (the label that the Sierra Leone clerks applied to the final column of the liberated Africans' register, which provided details on what happened to these Africans after the court proceedings). Third, we must recognize that recaptives would not necessarily accept the role that officials assigned to them, and even when they did, that role - an 'apprenticeship' for example - was usually limited to a term of years. What can we say about the ultimate fate of recaptive Africans? More, it turns out, than for any other major category of ex-slaves in the nineteenth century. We can address the question of just how 'liberated' they were, seek common threads in their disparate histories, as well as throw new light on the values of the broader Atlantic world in which most had to make a new home.

\section{SIZE AND DISTRIBUTION}

Table A.I in the Appendix at the end of this article provides a summary of how Liberated Africans came into existence as well as a basis for assessing the effectiveness of efforts to suppress the slave trade. Column I counts all vessels captured after I 807 whether or not they had slaves on board at the time of detention. ${ }^{2}$ Columns 2 and 3 count slaves, but include only those vessels that either had slaves on board at the time of detention, or whose slaves were taken into custody after landing. Column 2 estimates the number embarked, and column 3, those who survived long enough to be disembarked after capture. A comparison of columns I and 2 indicates that only one in three of the slave vessels that were intercepted actually carried slaves at the time of capture. We now know that about 9,000 separate ventures either carried slaves from Africa to the Americas or attempted to do so after I $807 .{ }^{3}$ Of this 9,, 00 , Table A.I suggests that less than one-quarter were detained. And as 2.8 million enslaved Africans disembarked in the same period of whom just I 8 I, 000 became recaptives then we can say that the combined antislave trade squadrons of the Atlantic naval powers managed to divert only about six per cent of those carried off from Atlantic Africa. ${ }^{4}$

The great majority of recaptives passed through administrative processes that formally documented their new status. The best known was adjudication in international courts (termed Courts of Mixed Commission) that resulted from a series of treaties between

2 For a discussion of the measures adopted by the governments of Britain, Portugal, Spain, France, and the United States, see D. Eltis, Economic Growth and the Ending of the Transatlantic Slave Trade (New York, I987).

3 Derived by dividing the total number slaves carried from Africa at Voyages: The Trans-Atlantic Slave Trade Database (STDB), (http://slavevoyages.org/tast/assessment/estimates.faces? yearFrom=ı 808\&yearTo=I 866), by the average number of slaves embarked per voyage at (http://www.slavevoyages.org/tast/database/search. faces), new edition, forthcoming 2014.

4 Of course, not all of the slave trade carried on after I 807 was illegal and subject to interdiction. The year I 807 is when the British and US formally pulled out of the trade. The very large traffic to Cuba was lawful until I 820 and to Brazil until I830. A calculation of capture rates that took this into account would double the share of slaves captured. Nevertheless, the antislave trade squadrons operating in the Atlantic never came close to achieving their objective. See Eltis, Economic Growth, for an overview. 
the British and five other nations (Spain, Brazil, United States, Portugal, and the Netherlands). Such courts were established at different times in Freetown (Sierra Leone), Luanda (Angola), Cape of Good Hope, Rio de Janeiro, Paramaribo (Surinam), Kingston (Jamaica), Havana, and New York. Together they condemned 567 vessels and declared 84,700 Africans liberated-close to half of all recaptives. The great majority of these66,600-were registered by the various Mixed Commission Courts at Sierra Leone, with another $\mathrm{I} 2,200$ in Havana, 5,800 in Rio de Janeiro and I37 in Luanda. ${ }^{5}$ None of the Mixed Courts in other locations actually freed any slaves. A slightly smaller group of 75,600 emerged into Liberated African status via British Admiralty Courts. These were strictly domestic tribunals that had jurisdiction over maritime matters. Almost every maritime nation had such institutions. In the UK they were called Vice-Admiralty courts with the High Court of Admiralty acting as the appellate court in London. Similar courts in the US liberated 6,346 people. Those of other nations liberated a further 8,000 Africans. Brazil $(4,878)$ formed the core of this group, but Portuguese tribunals in Africa $(2,000)$, and French courts (967) also contributed. ${ }^{6}$ And historians have largely ignored the contribution of the new government of Haiti whose navy detained three slave ships between I 8 I I and I8I9 containing 808 Africans. Finally, at least 2,400 other Africans should be included in the group even though they passed through no formal process - mostly as a result of surviving the wreck of their slave ships on islands in the British Caribbean while en route to Cuba.

Where did Liberated Africans come from and where did they go? Redistributing the data in Table A.I provides a preliminary answer to these questions and reveals several interesting patterns. First, how representative of the total slave trade was this group of I 80,969 ? Table A.2 shows the coastal regions of embarkation for the recaptives, and compares their distribution with that of the whole 2.8 million deportees carried off from Africa after I 807 . Because the coastal origins of slaves changed sharply over time, the Table presents two periods - before $\mathrm{I} 840$ and after I 839 . In the earlier of the two, when 62 per cent of recaptures occurred, an overwhelming proportion came from West Africa-mostly Sierra Leone, and the Bights of Benin and Biafra. After I 839, by contrast, an even larger proportion of the recaptives came from Africa south of the equator. In this second period they were much more representative of the mix of all people pulled into the slave trade. Portuguese refusal to ban all slave trading at once was the main reason for the shift in the coastal origins

5 Figures calculated from STDB except for Luanda, which draws on S. Coghe, 'The problem of freedom in a mid nineteenth-century Atlantic slave society: the Liberated Africans of the Anglo-Portuguese mixed commission in Luanda (I 844-I870)', Slavery and Abolition, 33:3 (2012), 479-500. Note that for Sierra Leone and Havana the figures provided here are greater than those generated by a count of Africans listed in the court registers. This is explained first, by deaths immediately after disembarkation and second, by the fact that several thousand captives whom the courts declared free disembarked from the slave ship before the vessel was conducted to Sierra Leone or Havana.

6 The Brazilian total does not include 729 Africans liberated in Bahia from the Ultimação (I8 $5 \mathrm{I}$ ), Relâmpago (I85I), and Mary E. Smith (I856). For these, see Arquivo Nacional, Rio de Janeiro (ANRJ) AM IJ 6 Pasta 525, 'Relação dos 729 Africanos aprendidos em 8 de Setembro e 30 de Outubro de I85 I e 30 de Janeiro de I856', 3 Apr. I86I. More records of Liberated Africans in Brazil will come to light as provincial and municipal archives are searched. We thank Daryle Williams of the University of Maryland for this information. 
of recaptives. The Anglo-Portuguese treaty of I8I 5 meant that most of the traffic south of the equator remained legal until I 830 and therefore off-limits for the British navy. And not until the very end of the 1830 s did the strength of the British antislave trade squadron south of the line match its northern counterpart. It is also significant that in I839, Britain initiated major ground operations in West Africa in the form of a large raid on the slave factory at Lomboko, Sierra Leone. ${ }^{7}$ Moreover this was also the year that Yoruba recaptives made the first voyage back to Badagry from Sierra Leone. ${ }^{8}$ Slave traders thus increasingly found a more hospitable environment south of the equator.

Coastal region of embarkation tells us only a little about who the recaptives were, but we do not have to leave the question of origins there. The transatlantic slave trade was always dominated by a relatively small number of major embarkation locations. Except for Sierra Leone and the Windward Coast, slave vessels did not usually buy slaves from scattered points along a wide stretch of coastline. In the nineteenth century, this tendency toward geographic concentration became even more pronounced. Just two major ports dominated each of three of the four major coastal regions in Africa that embarked slaves - the Bight of Benin, the Bight of Biafra, and Upper Guinea. More than four out of five deportees leaving the Bight of Benin passed through Ouidah and Lagos. Nearly three-quarters leaving the Bight of Biafra left from Bonny and Old Calabar, and two thirds from Upper Guinea went through Gallinas and the Rio Pongo before I 840. The large West-Central Africa region had a somewhat less concentrated pattern of departures in the early period (I808-39), but Ambriz, Luanda, Benguela, the Congo River, and Cabinda accounted for two-thirds of departures over the whole period. Thus, from I 808 to I 839 , there was a more than 50 per cent chance that a liberated African would have passed through Ouidah, Lagos, Bonny and Calabar - ranging over just three hundred miles of what is today Benin and Nigeria.

Beyond coastal geography, there is the question of the geographic profile of the origins of slaves in the interior. A database derived from the registers of liberated Africans kept by the Mixed Commission and Vice-Admiralty courts contains information on 92,230 individuals including African names for almost all of them and, in some cases, a designation for 'country'. So far the identification of the ethnolinguistic associations of 33,000 of this group offers the prospect of outlining such a profile. Many of these names provide new details of links between origins and coastal points of departure. ${ }^{9}$ Space constraints here dictate a very brief overview of our findings with the main presentation reserved for a separate paper. Naming patterns suggest that the vast majority of slaves came from within two hundred miles of the Western African coast. Kissi, Mandingo, Susu, Mende, Temne, Fula, and Sherbro made up more than 70 per cent

7 This slave factory complex plays a prominent part in the Steven Spielberg film Amistad, in which it is misleadingly portrayed as a single large castle.

8 See petition by Aku residents in Sierra Leone in The National Archives, London (TNA) Colonial Office (CO) 27/I 2/37, as cited in C. Fyfe, A History of Sierra Leone (Oxford, I962), 2 I 2; and J. H. Kopytoff, A Preface to Modern Nigeria: The 'Sierra Leoneans' in Yoruba, I830-1890 (Madison, WI, I965), 44.

9 For a discussion of these registers, see R. Anderson et al., 'Using African names to identify the origins of captives in the transatlantic slave trade: crowd-sourcing and the registers of Liberated Africans, I8०8I 862', History in Africa, 40:I (2013), I65-91. H. Lovejoy makes similar use of the Havana Mixed Commission Court register in 'Old Oyo influences on the transformation of Lucumí identity in colonial Cuba' (unpublished PhD thesis, University of California, Los Angeles, 20I2). 
carried off from the Gallinas and Rio Pongo. ${ }^{\text {Io }}$ Preliminary results indicate that 95 per cent of the 8,30I departures from the Bight of Benin ports of Ouidah and Lagos were Yoruba-speakers, a proportion well in excess of current estimates. Egba, Ijebu, and Oyo subgroups predominate with the area west of the two ports underrepresented. Further east the Igbo were equally dominant accounting for 88 per cent of the $8,4 \mathrm{IO}$ so far identified as leaving Bonny and Old Calabar. This also is a higher ratio than the current literature supports. ${ }^{\mathrm{II}}$ For Luanda, Benguela, Ambriz, Cabinda, and the Congo River, the major points of departure for West Central Africa, the new material also challenges the prevailing scholarly consensus. While only about 3,000 recaptives can be traced to this huge region, an I 855 register of slaves and slave ownership in Angola is an important additional source. This new material suggests that the Lunda Empire in north-eastern Angola was probably much less important as a source of slaves in the nineteenth century than scholars have thought. ${ }^{\mathrm{I}}$ In fact, the great majority of recaptives appear to have originated north and south of Portuguese Angola, from among the Kimbundu, Kikongo, and Umbundu speaking people, rather than from the Lunda territory. This constitutes a shift from the pre-I 830 picture drawn by Joseph Miller, where caravans of slaves marched from regions as distant as the Zambezi River. ${ }^{\mathrm{I} 3}$

The ultimate origins of the recaptives is important not just for African history, but for anyone interested in the influence of Africa on the Americas and in the making of the Atlantic world. Well over half, or 45,000 of the group for whom it is possible to trace African origins was on its way to Cuba at the time of their detention. Another 17,000 were heading for Salvador da Bahia, Io,000 to Rio de Janeiro, and I,500 to the French Caribbean. There is no reason why the cultural backgrounds of these Africans should have been any different from the coerced migrants whose transatlantic voyage was not interrupted by a naval cruiser. Any conclusions that can be drawn from the pool of recaptives will hold for the larger group that completed the transatlantic voyage as intended.

Having sketched out the size and origins of the recaptive diaspora we should now track what subsequently happened to them. As Table A.I shows many died before they reached Sierra Leone or St Helena, much less the Americas. Indeed the great majority of those on board captured vessels experienced a voyage that was little different in mortality and morbidity from those that were sold into the slave markets of Brazil, Cuba, or the French Caribbean. A voyage from, say, Bonny to Sierra Leone after capture could take

Io P. Misevich, 'The origins of slaves leaving the Upper Guinea coast in the nineteenth century', in D. Eltis and D. Richardson (eds.), Extending the Frontiers: Essays on the New Transatlantic Slave Trade Database (New Haven, CT, 2008), I 55-75.

I I D. Northrup, Trade Without Rulers: Pre-Colonial Economic Development in South-Eastern Nigeria (Oxford, I978), 62, estimates 60 per cent Igbo among departures from Bonny, New Calabar, and Old Calabar; Lovejoy, 'Old Oyo', 67, estimates 75 per cent of those leaving Bight of Benin ports were Yoruba.

I 2 D. B. Domingues da Silva, 'Crossroads: slave frontiers of Angola, c. I780-I867' (unpublished PhD thesis, Emory University, 20II), ch. 3; D. B. Domingues da Silva, 'The origins of slaves leaving Angola in the $9^{\text {th }}$ century: primary results from field work' (unpublished paper presented to the European Social Science History Conference, Lisbon, February, 2008); and R. Ferreira, 'The suppression of the slave trade and slave departures from Angola, I830s-186os', in Eltis and Richardson, Extending, 3 13-34.

I3 J. C. Miller, Way of Death: Merchant Capitalism and the Angolan Slave Trade, I730-I830 (Madison, WI, I988). 
almost as long as a voyage from Bonny to the eastern Caribbean. ${ }^{\mathrm{I} 4}$ Those surviving to be entered into the registers of Liberated Africans faced a wide range of possible fates, and in assessing outcomes we have to take into account the motivations of both judicial authorities and recaptives themselves.

Table A. 3 shows where the recaptives were taken after their vessels were intercepted. The Table breaks down the initial destinations of the recaptives into the two broad categories of first, the Americas, shown in the top half of the Table, and second, 'Africa and other' (in effect the Old World) in the lower half. The first column of numbers shows initial arrivals in each region while the second displays the subsequent relocation of the liberated Africans into (shown by a plus sign) and out of (shown by a minus sign) each region. But the second column certainly lacks the precision of the first. Where the cells are marked 'unknown' we can assume that movements either way would have been very small: there is no evidence of large movements of Liberated Africans out of Antigua, Bahia, or the Cape of Good Hope. One major exception to this statement, however, is Sierra Leone. Table A.3 shows 99,466 arriving in Freetown, and I 5, I 34 leaving, but the latter figure is understated. Many of the recaptured Africans originated from the area surrounding the British colony and simply opted to return home. Until I8I3, clerks in Sierra Leone kept annual lists headed 'Alterations to the Register of Liberated Negroes'. For 77 cases they recorded 'left the colony' or 'returned to his [or her] country', and for a further 78 the entry is 'runaway'. All but three of the first group and twenty of the runaways were native to Sierra Leone and the surrounding areas. More important are the missing unique registration numbers in the 'Alterations' lists. These are explained by a note at the end of the document, '[t]hose captured negroes that are not accounted for have deserted to native towns in the back parts of the country'. ${ }^{15}$ Some Yoruba left Sierra Leone for Fula regions in an attempt to get back home, but the overwhelming share of the missing group were adults who had arrived on vessels captured as they left Gallinas, the Rio Pongo, and other embarkation points in and adjacent to Sierra Leone. Table A.2, column I, indicates that 22,000 Liberated Africans had originally embarked in regions adjacent to Sierra Leone. If even half of this number opted to subsequently leave the colony then the I5, I 34 departures from Sierra Leone in Table A.3 should be increased to perhaps 26,000.

A comparison of upper and lower panels in Table A.3 indicates that almost threequarters of recaptive Africans initially disembarked in sub-Saharan Africa (including St Helena), though usually far away from home base. Sierra Leone took in more than the rest of the Atlantic world combined, and of those carried to the Americas, most disembarked in the major plantation regions outside the US. Just as they had dominated the slave trade, British, Brazilian, and Spanish territories also received most of the Liberated Africans who initially landed in the Americas. This pattern becomes even more pronounced when we allow for the subsequent movement of recaptives after their disembarkation. Column 2 of Table A.3 shows that at least 25,000 did not remain in their first disembarkation region - in some cases voluntarily, and in some cases, not. There were

\footnotetext{
I4 D. Northrup, 'African mortality in the suppression of the slave trade: the case of the Bight of Biafra', Journal of Interdisciplinary History, 9: I (I978), 47-64.

I 5 TNA CO 267/35; TNA CO $267 / 38$.
} 
three types of secondary movement: one, as already noted, resulted from recaptives attempting to go home, and flowed from Sierra Leone to other parts of Africa; a second essentially followed the path of the transatlantic slave trade and went from Sierra Leone and St Helena to the British Caribbean (including British Guiana); a third redistributed the recaptives from one part of the Americas to another, usually from Brazil and Cuba to again, the British West Indies. ${ }^{16}$ Yet it needs to be stressed that even after making reasonable allowance for the unknowable number of Africans who left Sierra Leone to return to their African home, most Liberated Africans remained close to their initial landing site. Thus, Sierra Leone was easily the largest ultimate (as well as initial) destination of Liberated Africans. But the British Caribbean was easily the second largest. Adding initial arrivals and relocated individuals together, the British Caribbean received probably 5,, 000 recaptives (compared to a net influx into Sierra Leone of approximately 60,000).

Within the British Americas it is hardly surprising that the three largest sugar- producing colonies in the I 840 - Jamaica, British Guiana, and Trinidad - claimed over 80 per cent of the relocated recaptives. Agents for these colonies lobbied aggressively for immigrants in the aftermath of British abolition of slavery, especially after the premature expiry of the apprenticeship period in I838. From I 840 to I862 almost all 3 I,000 Liberated Africans who left St Helena and Sierra Leone (at least by sea) went to one of these three colonies. A further 5,000 entered Trinidad and British Guiana from Havana and Rio de Janeiro after negotiations between British, Spanish, and Brazilian governments. Breaking this pattern were the six thousand taken from west to east-from Key West, Florida, where in the late I 85 os those detained by the US Navy were held after capture - to Liberia. Nine hundred came to the Bahamas from Cuba, and several hundred others were sent south to Patagonia from Buenos Aires in the late I 820 s. Plantation agriculture can explain nothing of these last three cases.

\section{LIBERATION AND VOLITION}

How much volition there was in any of these movements is of central interest. More broadly, what was the status of Liberated Africans after they emerged from the legal process triggered by their interception? Just how 'liberated' were Liberated Africans? Scholars can point easily enough to examples of recaptives laboring for others in an apparently permanent slave-like dependence, as in Antigua, Tortola, or in Rio de Janeiro. At the other end of the spectrum were settlements or villages in which recaptives engaged in subsistence agriculture, mainly in Sierra Leone. Generalizations are indeed a challenge. Our analysis counterposes the expectations of those responsible for the detention of the slave vessels with the likely expectations of the Liberated Africans themselves. Africans who became recaptives, and Europeans trying to suppress the slave trade could

I6 R. M. Adderley, 'New Negroes from Africa': Slave Trade Abolition and Free African Settlement in the Nineteenth-Century Caribbean (Bloomington, IN, 2006); J. U. J. Asiegbu, Slavery and the Politics of Liberation, I787-I86I: A Study of Liberated African Emigration and British Anti-Slavery Policy (New York, I969); M. Schuler, 'Alas, Alas, Kongo': A Social History of Indentured African Immigration into Jamaica, I84I-I865 (Baltimore, I980); M. Warner-Lewis, Guinea's Other Suns: The African Dynamic in Trinidad Culture (Dover, MA, I99I). 
agree that freedom meant the absence of slavery. Beyond this, however, there was no consensus on what terms of labor should replace slavery.

On the European side, section VII of the British Slave Trade Abolition Act required that recaptives either enlist in the armed forces or be bound 'whether of full Age or not, as Apprentices, for any Term not exceeding Fourteen Years'. Further, this arrangement should have 'the same Force and Effect as if the party thereby bound voluntarily so enlisted or entered [the apprenticeship]'. The Act also denied enlisted men a pension upon discharge, and in addition empowered the Government to establish 'Regulations for the future Disposal and Support of such Negroes as shall have been bound Apprentices ... after the term of their Apprenticeship shall have expired... as may prevent such Negroes from becoming at any Time chargeable' to the public purse. ${ }^{\mathbf{I 7}}$ An Order in Council issued in March I 808 laid out the guidelines. Masters and mistresses should be 'prudent and humane' and should impart 'trades, handicrafts or employment' that would enable the apprentices 'to gain their livelihood... when their apprenticeship should expire'. ${ }^{\text {I }}$ Military Recruitment was to have priority, however, perhaps because the Act was passed in the middle of the Napoleonic Wars.

At a deeper level the motives behind section VII were the same as those behind the poor law, the truncated apprenticeship that followed slavery in British territories from I 834, and various devices such as head taxes and restrictions on land use that were to evolve in the non-settler parts of all European Empires in the nineteenth and twentieth centuries. Section VII was both harbinger of and a link between domestic and overseas policies toward labor. The intention in all cases was to extract more labor service from people than they would have been prepared to volunteer, even with higher wages but with as little as possible overt compulsion. By the early nineteenth century, British elites were convinced of the superiority of free labor. They wanted employers and a contented though subservient laboring population instead of slave owners and slaves, and an environment where fear of want had replaced dread of the lash. ${ }^{\text {I9 }}$ An apprenticeship was viewed as a way of repairing perceived damage that slavery inflicted on the work ethic and thus it prepared the apprentice for wage earning. Slave owners, however, were more likely to see apprenticeship as a way of prolonging slavery.

Other countries followed the British lead. A Portuguese decree issued in I 8 I 8 in the aftermath of the Anglo-Portuguese slave trade abolition treaties adopted the above provisions, and while the I83 I Brazilian slave trade abolition act specified that all recaptives should return to Africa, this never in fact happened and there, too, most emancipados served out fourteen-year terms. ${ }^{20}$ The US, as noted, went one step further and actually

I7 In Sierra Leone an I 808 colonial act declared that apprenticeship would be legal only if the names of both the apprentice and his or her employer be entered into a register kept by the Governor. Moreover, the Governor had to be notified in writing of any changes by either party within 24 hours. See TNA CO 267/24, fn. 30 , Sierra Leone Gazette, 20 Aug. I808.

I 8 R. R. Kuczynski, Demographic Survey of the British Colonial Empire, Volume I (London, I948), II3.

I9 H. Brougham, An Inquiry into the Colonial Policy of the European Powers, Volume I (Edinburgh, I803), 507-I 8; and the sources cited in D. Eltis, 'Abolitionist perceptions of society after slavery', in J. Walvin (ed.), Slavery and British Society, I776-I846 (London, I982), I95-2I3.

20 B. G. Mamigonian, 'In the name of freedom: slave trade abolition, the law and the Brazilian branch of the African Emigration Scheme (Brazil-British West Indies, I830s-I850s)', Slavery \& Abolition, 30:I (2009), 4I-66; 
did dispatch more than five thousand to Monrovia. These were all on board vessels detained by US cruisers after I8I9-prior to which any Africans removed from a slave ship had usually been sold into the slave populations of the Southern States. ${ }^{2 I}$ The Liberian stream comprised mainly children who were apprenticed out to American and Americo-Liberian families. The term of the apprenticeship varied from seven to fourteen years, with presumably age having a major influence on individual terms. A disproportionate share of the newcomers worked for and participated in church missions thanks to the US government subsidizing the indentures. This no doubt helps explain why US settlers in Liberia generally welcomed the new arrivals, but some of the new arrivals, ironically, ended up working in the small sugar cane sector that appeared briefly in mid-century Liberia. Finally the Argentine government assigned the status of 'libertos' to most of the nearly I,500 recaptives removed from Brazilian slave vessels by Argentinian privateers between 1825 and I828-the slave trade having been abolished at independence in I 8 I . But libertos were also required to serve as 'apprentices' for ten years and were sold by the privateers at an open market.

It is difficult to know how the I $8 \mathrm{I}, 000$ Africans felt about any of this. ${ }^{22}$ Ex-slaves in the US aspired to 40 acres and a mule, and their post-I 838 counterparts in Jamaica, Trinidad, and Guiana quickly left the plantations to till their own smallholdings when the opportunity arose. The English working class was perhaps not much different given that Chartists in the I840s organized a lottery, the winners of which would receive a small farm. And mid-century US workers viewed wage work as a step toward acquiring land in the west. Whereas today's migrants move to improve incomes, for long-distance voluntary migration in the early modern period gaining access to new land resources was paramount, or, put another way, access to conditions that might give the migrant more control over his or her own life. We might assume that the goals of Liberated Africans after violent removal from their native societies were not much different. Recaptive responses examined in more detail below make clear that many were unhappy with their new status, as well as the enslaved condition that they had recently left behind. It seems safe to say that there was nothing in the various slave trade abolition acts that met their aspirations with the single exception that for the most part they would not become chattel slaves and were provided with food and shelter for varying periods. The strength of this feeling was apparent in I $8 \mathrm{I} 2$ when six 'natives of Africa' on board the condemned slaver S Miguel Triunfante petitioned against being entered in the Liberated African register 'having declared themselves

B. G. Mamigonian, 'Conflicts over the meanings of freedom: the Liberated Africans' struggle for final emancipation in Brazil (I840s-I860s)', in R. Brana-Shute and R. J. Sparks (eds.), Paths to Freedom: Manumission in the Atlantic World (Columbia, SC, 2009), 235-64.

2 I K. F. Younger, “"Africa stretches forth her hands unto you”: female colonization supporters in the antebellum United States' (unpublished PhD thesis, Pennsylvania State University, 2006); K. F. Younger, 'Liberia and the last slave ships', Civil War History, 54:4 (2008), 424-42.

22 For some indication see O. Ojo, 'John Baptiste Dasalu or Nicolas Lucumi and the nineteenth-century Cuban-Lagos connection', paper presented at the Kitchener-Waterloo Black History Month Workshop, 4 Feb. 2008; P. D. Curtin (ed.), Africa Remembered: Narratives by West Africans from the Era of the Slave Trade (Madison, WI, I967), I99-333. 
freemen and never that they were slaves'. The court agreed and indeed they do not appear in the register. ${ }^{23}$

Examining all the Liberated African data together establishes that which side of the Atlantic the recaptive disembarked had a major impact on African abilities to shape their post-disembarkation experiences. In the British Caribbean 'liberation' from a slave ship initially meant many years of unpaid labor. The main difference from slavery was that the status was not heritable, was usually time limited and females could not be employed in agriculture. Thus in Tortola and the Bahamas, a I4-year indenture was the norm (with some, mainly females, set at seven and ten in the Bahamas) until I828, but thereafter shorter terms were still enforced for new arrivals down to I860-27 years after the British abolished slavery. In Brazil, still under Portuguese jurisdiction when the first emancipados arrived in I82I, a decree modeled on the I807 act complete with a I4-year apprenticeship term was still in effect. ${ }^{24}$ However, the first Brazilian abolition law, of 7 November I83 I, made no mention of a fixed term and simply required-like its US predecessor - that all slaves removed from slave ships be sent back to Africa. In fact this never happened. Instead, emancipados were informed of their status and then hired out - sometimes via public auction - to 'private persons and public institutions' without a term limit. It was eventually decided that those recaptured before the ${ }^{8} 8$ I law were liberated after I 4 years, but anyone who became a recaptive after the I 83 I law was subject to permanent indentured servitude mostly on public works. Decrees of I 853 freed the minority of emancipados still working in the private sector with the rest receiving similar status in $\mathrm{I} 864$, but by then both groups on average had worked as involuntary laborers far beyond I4 years. ${ }^{25}$ As already noted, Cuban emancipados detained by the Spanish colonial authorities or handed over to the latter by the Mixed Commission Court in Havana fared even worse than slaves because they were not permitted access to Coartación - the right to purchase their own freedom. Of the I0,799 arrivals in Cuba shown in Table A.3, various captain-generals eventually freed just over 2,000 and the British removed a further 4,000 to mainly Trinidad between 1833 and I 849 , but none of the remainder was liberated before I $870 .{ }^{26}$ Freedom, however defined, was a remote prospect.

On the other side of the Atlantic, by contrast, the terms were much shorter. The first I67 recaptives taken into Sierra Leone were on board the Eliza and the Baltimore, US slave ships that the British captured in March I 808. The slaves were initially sold as 'apprentices'

23 TNA High Court of Admiralty (HCA) 32/I836, part 2, the S Miguel Triunfante case (voyageid 7627).

24 A. Rupprecht, "When he gets among his countrymen, they tell him that he is free": slave trade abolition, indentured Africans and a royal commission', Slavery and Abolition, 33:3 (20I2), 435-55. In addition, the commander of the squadron that had captured the vessel carrying the first arrivals illegally dispatched 107 recaptives to work on his own sugar estate in Trinidad. This decision was never challenged.

25 B. G. Mamigonian, 'To be a Liberated African in Brazil: labour and citizenship in the nineteenth century' (unpublished $\mathrm{PhD}$ thesis, University of Waterloo, 2002), 48-134 and 193-4; D. Williams, The Broken Paths of Freedom: A Spatial History of Free Africans in Nineteenth-Century Brazilian Slave Society (forthcoming).

26 D. R. Murray, Odious Commerce: Britain, Spain, and the Abolition of the Cuban Slave Trade (Cambridge, I980), 27I-97. Note that the I0,799 comprise only those on board vessels processed by the Havana Mixed Commission Courts. A further $\mathrm{I}_{5}, 000$ became emancipados as a result of Cuban colonial intervention in the slave trade after $\mathrm{I} 835$, usually as a result of detention on land immediately after disembarkation. These are not included in the definition of Liberated Africans used here (see Appendix). 
and down to I8I I they were advertised for resale in the Sierra Leone Gazette and African Herald. The documents do not indicate the length of indentures though we know that Zachary Macaulay, abolitionist and former governor, thought seven years was appropriate. A new governor, Thomas Perronet Thompson, who arrived after the detention of the first slave ships, declared such apprenticeship arrangements to be equivalent to slavery. He also claimed that abolitionists like Zachary Macaulay, James Stephen, and William Wilberforce who supported the apprenticeship plan were thereby guilty of sustaining slavery and the slave trade. Thompson canceled the indentures and the recaptives showed up in the registers for the first time in $1809 .{ }^{27}$ Yet Thompson and his successors attempted to regularize the institution rather than abolish it. They set the length of an apprenticeship according to age, in a parallel to the treatment of wards of the parish under the English poor law. The disposal column of the Sierra Leone-based registers for the first I,99 I recaptives landed at Freetown has information for $58 \mathrm{I}$ individuals that apparently survived on a random basis. In addition, down to I8I4 the colonial authorities kept an annual 'Alterations' list intended to record changes in status. Combining these sources makes it possible to extract some information on what happened to I,73 I of the first 4,207 recaptives processed by the Freetown Vice-Admiralty court. ${ }^{28}$ Not all of these recaptives were apprenticed, but for those who were, the registers record the term of service for 393 individuals. The clerks estimated just under half of these ( 176$)$ to be adults ( 15 years of age and older) and this group was apprenticed for a mean of 3.04 years. No recaptive over I 7 was assigned a term of more than three years. The remaining 217 , all under I 5 years of age, received longer terms ranging indeed, up to the I4 years specified in the abolition act. Age and term were thus inversely related, with five year-olds averaging 13 -year apprenticeships and I4 year-olds averaging 3.7 years and so on. ${ }^{29}$

They may have disagreed on the terms and conditions, but both abolitionists and their critics, such as Thompson and Justice Robert Thorpe, wanted the Sierra Leone recaptives to serve a term of indentured servitude, and of course the British West India regiments needed recruits. Nevertheless the preferences of recaptives together with the Sierra Leone environment prevented the full implementation of the apprenticeship system. Not only was the indenture term shorter than what the British elite thought desirable, but the

27 S. Schwarz, 'Reconstructing the life histories of Liberated Africans: Sierra Leone in the early nineteenth century', History in Africa, 39: (2012), I94-20I; M. J. Turner, 'The limits of abolition: government, saints and the "African question”, c. I780-I820', English Historical Review, II2:446 (I997), 340 and 352-3. Thompson polarizes historians as well as contemporaries. Compare Turner's assessment with Fyfe's brusque treatment in A History of Sierra Leone, I05-II. Oddly, while Thompson argued strongly that recaptives did not need apprenticing and should be freed immediately, he nevertheless presided over the issuing of several hundred apprenticeships for Liberated Africans between July I 808 and February I 8 I० including those whom he had taken back from their masters/mistresses.

28 Extracted from TNA CO 267/24, CO 267/3 I, CO 267/35, CO 267/38, and the Sierra Leone National Archive (henceforth SLNA), Liberated African Register numbered I-3772. The missing data are sometimes the result of illegible handwriting and sometimes there are simply blank pages. There is no obvious systematic explanation for such lacunae. The fact that the CO 267 material contains information on disposal that is not available in the Sierra Leone register for the same individuals suggests that a completely separate register on disposal once existed.

29 The Pearson Product Moment Correlation of age and term of service is -0.9, significant at the one per cent level. 
great majority of women were not subject to any apprenticeship. Reflecting European constructions of gender, the I 808 Order in Council stated, 'they (women) are not to be employed... in the labours of Agriculture', but the disposal column describes threequarters of them prior to I 8 I 4 as 'Living with a Liberated African', 'settled in the colony', 'settled in the mountains', or 'living with her countrymen'. The person or village is often identified. $^{30}$ Among 453 men for whom information survives at the end of I8II, I06 were enlisted in the Royal African Corps or Royal Navy, I34 were 'laborers' and I 22 were still under apprenticeship (all of them arriving in I 809-II). Only three were tradesmen and most of the remainder were described as 'living in the colony'. More important, for most years between I 8 I 4 and the beginning of coerced migration from Sierra Leone and St Helena to the British sugar colonies a quarter century later, the great majority of both men and women appear to have gone direct from the Liberated African yard to a recaptive village. The I 8 I 8 census summary enumerated 6,406 Liberated Africans (excluding enlisted men), but only 9 per cent were apprenticed, all but 103 of this group being children. Two years later the apprentice ratio had fallen below 8 per cent, again almost all children. By this time even most of the children were distributed across the recaptive villages. Despite the grand intentions of the I 807 Act, the I 808 Order in Council, and the stated motives of the abolitionists, apprenticeship for adults was rare.

The contrast with the experiences of the first Africans 'liberated' in the Americas (Tortola, Bahamas) is striking. While the imperial legislation applied to both sides of the Atlantic - section VII specified a maximum term, but no minimum - the lack of an export economy and the availability of land for settlement in Sierra Leone ensured that recaptives exercised options that did not exist in the Americas. The initial three-year term and then the dropping of even this requirement for adults on the African side recognized this reality. In the plantation Americas the demand for labor and the wariness of the slave-owning elite toward free blacks dictated that liberty for recaptives was more severely curtailed and in some cases barely perceptible.

Forced recruitment for the army in Sierra Leone continued. The I 808 Order in Council stated that the armed forces had first refusal on able-bodied men, and the most common single disposal label until I8 5 was 'enlisted' in the armed forces-usually in the eight West India regiments that until I 807 had 'recruited' mainly slaves. ${ }^{3 \mathrm{I}}$ Of the grand total

30 Thus six weeks after their slave vessel was condemned, sisters Mary and Maria, numbered 46 and 48 in the first Sierra Leone register, are described as follows: Mary 'is married to her own Countryman. Lives with her Sister in a House built for them by their countrymen. Support themselves by washing etc. in different families' (TNA CO 267/24, 'Annual Report of the Natives of Africa received, enlisted, entered, apprenticed, or otherwise disposed of... Dec 3I, I808'). The I8II report has information on 436 women who had arrived in the previous three and a half years. Only 49 are described as 'Apprenticed', 30 had 'Returned to their country', and the rest were living with or married to free laborers or other Liberated Africans, or just 'Living in the Colony'. This latter category, the largest, comprised 58 women. In the I8I 2 and I 8 I 3 returns, references to apprenticeships for women are very few and almost invariably for domestic service. In the I 8 I 2 list, only 25 women are listed as apprenticed and in the following year only two. See TNA CO $267 / 3 \mathrm{I}$ and $\mathrm{CO} 267 / 35$.

3 I As the British commander-in-chief wrote in I 8 I I, 'Since the abolition of the slave trade the W. India regiments have had no means of Recruiting their numbers; and (there is a) ... danger of total annihilation of this Force.' Commander-in-chief Fredericks, Horse Guards, to Liverpool, 8 Aug. I8I I, TNA CO 267/32. For a fuller explanation of this issue, see Roger Norman Buckley, Slaves in Redcoats: The British West India 
of 7,833 recaptives arriving in Freetown before 18 I 6 (when the Bance Island recruiting station closed), 2,2 I I were drafted into the armed forces, including over roo women and girls. ${ }^{32}$ It seems that in this period most men under thirty were enlisted. Choice was no more an option in recaptive recruitment than it was for seamen impressed until I 8 I 2 by the Royal Navy. Recruits served in the West Indies, received pay, and, upon discharge after the Napoleonic wars did in fact receive pensions despite the terms of abolition act. Some took up the option of returning to Sierra Leone where they founded the villages of Waterloo, Gibraltar Town, and Wellington. Recruiting at a reduced level continued into peacetime, however. In the I 840 s, an average of 150 a year were enlisted and if this was typical for the whole $1816-40$ period then the total number enlisted over the whole Liberated African era included could have reached I2,000 for the army alone in Sierra Leone with a few thousand others serving on naval vessels. An unknown number, but many hundreds, entered the West India regiments from among those liberated in West Indies. ${ }^{33}$

From I 8 I6, almost all Liberated Africans were being sent to villages outside Freetown or into the mountains regardless of age and with no attempt to restrict their activities. As John Peterson describes it, settlement in villages began in late I 808 to accommodate those who were neither enlisted nor apprenticed. Three (Wilberforce, Leicester, and Regent), were in existence by early I 8 I 5 , but with the sharp reduction in enlistment and the collapse of apprenticeship there were twenty by $\mathrm{I} 820$. Other than government-supplied provisions these communities functioned independently of official supervision and, until I 8 I 6 , imperial approval. ${ }^{34}$ In July I 820,846 recaptives were living in villages that received no government support and this number increased rapidly thereafter. Neither the I 807 Act nor the I 808 Order-in-Council provided for (or even anticipated) such an African-based response to abolition of the slave trade, particularly the exodus home. Although soil fertility was poor and some abolitionist observers by I 840 were scathing most villages became selfsufficient, developed a degree of ethnolinguistic homogeneity, and offered low probabilities of re-enslavement. ${ }^{35}$

Regiments, I795-I8I5 (New Haven, CT, I979), I30-9. Those not fit for the military were assigned to civilian tasks. In the words of a British official, 'First in regard to such Male Negroes as from infirmity or age are not fit for military, or naval Service, or such as shall not be required or taken for the same as aforesaid and also in regard to female negroes, the Collector or Chief Officer of the Customs for the time being is to use the earliest and utmost endeavours to bind them as apprentices, or indentured servants... either in the same or other colonies to learn such trades handicrafts, or employments as they seem fit for and to gain their own livelihood most comfortably by, after their terms of servitude shall expire.' TNA CO 3I8/86, Commissioner Bowles to Wilmot Horton, I2 Mar. I825.

32 Buckley, Slaves, I3 I, presents and corrects the summaries tabulated in TNA CO 267/I27, 'Return showing the Number of Liberated Africans received into the colony of Sierra Leone ...' By going back to the original registers in Sierra Leone and Kew we have added 50 to the total of Liberated Africans and I 20 to the number of those enlisted as displayed in Buckley.

33 Kuczynski, Demographic Survey I, II6, counts 3,I74 recruits by I833, but this is probably low. The Sierra Leone register for I 845 to I 848 indicates that 6I 8 entered the Royal African Corps (SLNA, Liberated African Register numbered 75357-84420), and if this number was maintained in all post-I 8 I 5 years then a total of I0,000 plus departures is likely. Asiegbu in Slavery, 3I, estimated I2,000, which we accept here.

34 J. Peterson, Province of Freedom: A History of Sierra Leone, I787-1870 (London, I969), 45-59.

35 Richard Madden was commissioned to inspect the West African colonies in I84I. The section of his report on Sierra Leone was particularly bleak. See Parliamentary Papers, I842, XII (55 I), 'Report of the Commissioner 
As Table A.2 shows, more than four out of five recaptives originated in regions far removed from where their vessel was taken after capture. For most, the possibility of returning to their homeland was indeed faint. Given that, as one Sierra Leone observer wrote, 'Liberated Africans have no desire to leave their native soil', it was not just apprenticeship and forced recruitment that constrained their options. ${ }^{36} \mathrm{New}$ communities in a strange land comprised a distant second-best choice for most recaptives. Settlers did, however, gravitate toward or create villages in which people were most like themselves. Such a pattern was facilitated by the fact that new villages often resulted from a sudden inflow of people who had voyaged on the same slave vessel, and that slave vessels at this time rarely embarked slaves at more than one location. Indeed the Church Missionary Society encouraged recaptives to form homogeneous parishes or towns and Africans from captured vessels were more likely to be kept together in the aftermath of liberation. By contrast, slaves sold from a slave vessel that completed its journey to the plantation Americas were typically dispersed across the region and faced assimilation into largely African-American communities. There must have been many more 'shipmate' connections established and maintained among recaptives on both sides of the Atlantic than among those not recaptured. Also 80 per cent of the slave vessels that disembarked in Sierra Leone had arrived by $\mathrm{I} 845$ and it follows from Table A.2 that three-fifths of these village settlements must have had heavily Yoruba or Igbo components. It is rather surprising that while Sierra Leone has received a share of Africanists' attentions disproportionate to its size and population, scholarship on the creation and evolution of such communities is still in its infancy. Scholars of the diaspora have largely chosen to work on migration to the Americas rather than within Africa. ${ }^{37}$ Liberated African settlements in the Bahamas and Trinidad tended to supplement the colonial plantation economies and, like Africans elsewhere in the Americas, quickly 'went about the process of inventing functional African-Caribbean cultures' ${ }^{38}$ Their counterparts in Sierra Leone were more independent and self-contained both culturally and economically.

The major problem for the Sierra Leone settlers was the low laboring wages in a colony that exported small amounts of camwood and palm oil and yet had an average of 2,000 people a year added to its labor force in the $\mathrm{I} 83$ os and I $840 \mathrm{Os} .{ }^{39} \mathrm{~A}$ sugar plantation colony, Sierra Leone was not. Despite low wages and exile it is possible that of all the Liberated

of Inquiry on the West Coast of Africa'; and R. Anderson, “Particulars of disposal”: the social implications of re-captive settlement policy' (paper presented at Liberated Africans Conference, University of California, Irvine, I-3 Oct. 2013).

36 The African Repository and Colonial Journal, I 8:I I (I842), 293.

37 David Northrup took on the challenge in 'Becoming African: identity formation among liberated slaves in nineteenth-century Sierra Leone', Slavery and Abolition, 27:I (2006), I-2I. Also see L. Spitzer's Lives in Between: Assimilation and Marginality in Austria, Brazil, West Africa, I780-1945 (Cambridge, I989). Richard Anderson's forthcoming thesis will throw much needed light on this topic.

38 Adderley, 'New Negroes', especially the references to villages shown on p. 33. Quote is from pp. 238-9; I. Dookhan, A History of the British Virgin Islands, 1672 to 1970 (Epping, UK, I975), 97-II9.

39 Wages were lower than in British Guiana and Trinidad in the I830s and I840s. See the sources cited in W.A. Green, British Slave Emancipation: The Sugar Colonies and the Great Experiment, I830-I865 (Oxford, I976), 268-72; M. Schuler, 'Kru emigration to British and French Guiana, I84I-I857', in P. E. Lovejoy (ed.), Africans in Bondage: Studies in Slavery and the Slave Trade (Madison, WI, I986), I 5-20I; Schuler, Alas, 54-7. 
African options around the two Atlantic basins, the communities that formed in Freetown's hinterland came closer to meeting the aspirations of the recaptives themselves (as opposed to what abolitionists, planters, and imperial governments wished them to aspire to). Recaptive villagers in Sierra Leone had some volition. ${ }^{\circ}{ }^{\circ}$ They could leave the colony, look for waged work, enlist, participate in petty trade (in several cases, like John Ezzidio's, not so petty), or live on subsistence land. In the early I 840 , the additional option of emigrating to Jamaica, British Guiana, or Trinidad in return for a one-year indenture emerged as ex-slaves in the Caribbean abandoned the plantations to which they had been tied and the British briefly attempted to generate free migration from Africa. A further incentive for recaptives was the offer of a free return passage after a stay of five years. When this proved insufficient in the face of ill reports of the new environment, free migration virtually ended.

The experience of the Sierra Leone settlers should be seen as similar to other attempts of the tropical plantation colonies to attract transatlantic migrants as slavery came to an end. By I860 over 28,000 Madeirans had entered British Guiana, 3,800 British and Germans settled in Jamaica, and 2,500 Kru migrated from the Windward Coast to mainly British and French Guiana, all for terms ranging from one to five years. The Spanish had some initial success in attracting Canary Islanders to Cuba. But here as elsewhere in the Caribbean migration peaked before 1850 and African and European migrants alike, facing identical terms of labor, moved away from fieldwork on plantations at the earliest opportunity. ${ }^{4 \mathrm{I}}$ Broadly, European laborers' unwillingness to perform waged work in the sugar fields after the mid-I60os helped underpin the transatlantic slave trade to the French and British colonies. And in the mid-I8oos, when slavery was no longer permitted, the refusal of Europeans and Africans to migrate voluntarily to the sugar colonies triggered seventy years of contract labor that saw a million people leave India and China. ${ }^{42}$ Before the twentieth century, it was never possible to grow sugar commercially in the Americas without either slave labor or contract labor enforced by criminal sanctions.

As voluntary transatlantic migration dried up the British reinstituted a racially based coercive migration strategy. They revived their compulsory assignment policy of the early Freetown era and began dispatching newly arrived recaptives directly to the Caribbean. Negative incentives were employed in the form of cutting off provisions to those who refused to go. Between 1842 and 1863 , more than 30,000 were sent to the major British West Indian sugar colonies from Sierra Leone, St Helena and Rio de Janeiro.

40 By 'volition' we mean a narrower range of options than the term 'agency'. For a critique of the latter, see W. Johnson, 'On agency', Journal of Social History, 37: I (2003), I I3-24.

4 I D. Hall, 'Bountied European immigration into Jamaica, with special reference to the German settlement at Seaford Town up to I850', Parts I and 2, Jamaica Journal, 8 (I974), 48-54 and 9 (I975), 2-9; Schuler, 'Kru', I55-203; K. O. Laurence, 'The establishment of the Portuguese community in British Guiana', Jamaican Historical Review, 5:2 (I965), 50-7I; G. W. Roberts and M. A. Johnson, 'Factors involved in immigration and movements in the working force of British Guiana in the I9th century', Social and Economic Studies, 23:I (1974), 69-83.

42 S. L. Engerman, 'Servants to slaves to servants: contract labour and European expansion', in P. C. Emmer (ed.), Colonialism and Migration: Indentured Labour Before and After Slavery (Dordrecht, I986), 272. 
All of it was involuntary. ${ }^{43}$ British officials made the decision - often before the recaptives stepped off the slave vessel. This phase of transatlantic migration has been termed the new slave trade, and there was indeed little difference, prima facie, between British procedures and the French practice between I 848 and I 86I of buying slaves on the African coast and selling them as contract laborers in Reunion and the French Caribbean. ${ }^{44}$ Offsetting this to some extent was the option of changing employer in the Caribbean and the extension of the offer of free return passage after five years. While this was frequently not honored, several hundred did return to Sierra Leone (not shown in Table A.3) ${ }^{45}$ No such offer was available in St Helena where perhaps 95 per cent of the surviving recaptives relocated across the Atlantic. The cool climate, lack of arable land, and relatively high death rate on the island make it unlikely that many Africans would have chosen to remain even if given the opportunity. ${ }^{46}$ With a base pool of arrivals only one quarter the size of that in Sierra Leone, St Helena dispatched approximately the same numbers to the Caribbean and I,400 in addition to the Cape of Good Hope.

Children, too, were caught up in this process. According to the court registers those under the age of 15 made up over a third of the inflow to Sierra Leone and more than half of those taken to Liberia under the US flag. Initially apprenticed in and around Freetown, children were sent to the growing number of villages after I 8 I $5 \cdot{ }^{47}$ By January I8I9, 2, IO4 were attending school and for more than two decades thereafter almost all would have received some formal education. ${ }^{48}$ There is no evidence that children were sent out of the colony until the voluntary phase of migration to the West Indies began in the early I 840 s, at which point some 'recruitment' took place in the schools. When voluntary migration withered and recaptives were dispatched to the Caribbean direct from the Liberated African yard, children as well as adults were included. This pattern held through to 1848 when information on disposal ends. In St Helena formal education appears not have existed and obviously the question of volition cannot have arisen. For children,

43 For the best discussions of volition in the context of the African migration, see Adderley, 'New Negroes', 8 I-3; and Northrup, 'Freedom and indentured labor in the French Caribbean, I 848-1900', in D. Eltis (ed.), Coerced and Free Migration: Global Perspectives (Stanford, CA, 2002), 204-28.

44 Schuler, Alas, 23-7; Asiegbu, Slavery; F. Renault, Libération d'esclaves et Nouvelle Servitude: Les rachats de captifs africains pour le compte des colonies françaises après l'abolition de l'esclavage (Abidjan, I976), 35-7 I; Northrup, 'Freedom and indentured labor'. The length of indenture was five and later six years in the French Caribbean, compared to one and then three in British case. For Africans on the last slave ship wrecked in the Bahamas in $\mathrm{I} 860$, the term was raised to four years for adults.

45 Green, British Slave Emancipation, 274; Schuler, Alas, 88-9I.

46 Between 9 June I 840 and 27 Jan. I 844, one-third of the 6,708 Africans disembarked on the island had died by the end of the period. For a damning report on the facilities at Lemon Valley on the island by a naval surgeon, see Colonial Office to Palmerston, 27 Nov. I849, enc. 'Dr. Vowell's Report', TNA Foreign Office (FO) $84 / 779$, folios, I75-2 I 5. The last African brought into St Helena on a slave ship died in I929, and today there is no identifiable community of African descendants. See A. Pearson, B. Jeffs, A. Witkin, and H. MacQuarrie, Infernal Traffic: Excavation of a Liberated African Graveyard in Rupert's Valley, St. Helena (York, 20I I), I9 and 37.

47 The disposal registers are missing (or the disposal column is left blank) between I 8 I 4 and I8I6 and again between 1824 and 1840 , but this was the pattern until I 824 .

48 Parliamentary Papers, I 825, vol. XXV (520) 'Accounts relating to the duties, exports, imports; population; schools, churches, marriages, etc. of the colony of Sierra Leone', 23. Silke Strickrodt is currently examining education among Liberated Africans in nineteenth-century Sierra Leone. 
though not for adults (except convict transportation) there are again parallels to be found in the rest of the Atlantic. The government dispatched I60,000 British orphans to the Americas, South Africa, and Australasia between the early seventeenth and second half of the twentieth centuries without obtaining their consent. ${ }^{49}$

For Africans liberated in the Americas, the terms of labor improved slowly. Very few learned skills and, if they remained with the employer long enough to complete their indenture, they became unskilled laborers or domestic help. ${ }^{\circ}$ In the first few years after 1807 , the registers of Liberated Africans in Tortola, as in Freetown, specify the occupation of the master. Carpenter, sawyer, mason, fisherman, sailor, yeoman, and domestic are most commonly specified. But commissioners sent out first to Tortola and later to Antigua and the Bahamas between I82I and I 827 found the great majority of 'apprentices' to be unskilled. The British government canceled all existing apprenticeships in 1828 and for several years they required only one-year terms for Liberated African migrants. ${ }^{5 \mathrm{I}}$ But they also arranged that as many as possible were taken to the major sugarproducing colonies where their very presence increased the supply of labor, lowered wages, and reduced the costs of planters. Trinidad, British Guiana, Grenada, and Jamaica, it should be noted, still produced 40 per cent of the total sugar output of Cuba in I860, though by then the labor force was becoming Asian, at least in Trinidad and British Guiana. At mid-century, the situation worsened in the Americas as well as Africa. The Heroina was the last slave ship to wreck in the Bahamas-in I860-and yielded 389 survivors. Adults were made to serve five-year terms, children six, and most went to employers in Nassau. In the following year the British Colonial Office approved Trinidad legislation imposing a three-year term for newly arrived adult recaptives despite the fact that since 1849 only children had been apprenticed. ${ }^{22}$ We have found no record of schooling of any kind for Liberated Africans in any British West Indian colony with the exception of a handful in Jamaica apprenticed to the Basel mission, one of whom was Catherine Zimmerman Mulgrave. ${ }^{53}$

\section{CONCLUSION}

In summary, of the nearly I00,000 recaptives brought into Freetown, it is likely that substantially more than half settled in Sierra Leone or returned to the societies from which

49 Schuler, Alas, 23-9; R. Kershaw and J. Sacks, New Lives for Old: The Story of Britain's Child Migrants (Kew, 2008). British apologies for this policy have followed hard on a British prime minister's expression of 'deep sorrow' for the slave trade. Neither mentioned Liberated Africans of any age.

50 As one of the Commissioners sent to inquire into the status of Liberated Africans in Antigua wrote, 'It appears...that in the majority of instances the male African Apprentices had not been instructed in the trades, crafts, and employments, to which the wording to the Returns laid before Parliament stated they were originally indented, but that they had been chiefly employed either as Porters, Boatmen, or as domestic servants.' See TNA CO 3 18/86, Commissioner Bowles to Wilmot Horton, I2 Mar. I825.

5 I Rupprecht, “"When he gets”'; A. O. Thompson, 'African "recaptives” under apprenticeship in the British West Indies I 807-I 828', Immigrants and Minorities, 9:2 (I990), I 23-44.

52 Adderley, 'New Negroes', 60-I, 87-9.

53 D. Domingues da Silva, 'Catherine Zimmerman-Mulgrave: a slave odyssey', STDB, (http://slavevoyages.org/ tast/assessment/essays-mulgrave.faces), new edition, forthcoming $20 \mathrm{I} 4$. 
their forced migration had begun, mostly the former. ${ }^{54}$ In St Helena as we have seen all but a handful were moved to plantation colonies, but for a time, both here and in Sierra Leone, enough stayed behind that they comprised by far the largest ratio of Liberated Africans to host populations of any society in the Atlantic world after I808. Overall, relatively few went to the West Indies either voluntarily or involuntarily. The bottom half of Table A.3 suggests less than one quarter of the $\mathrm{I} 35,000$ total disembarking in the Old World moved to the Americas. Sierra Leone offered land for communities and some prospect of returning to their West African homelands. Whatever their motives, recaptives exercised a degree of choice in opposition to the preferences of a British colonial system that wanted all recaptives serving out long indentures in Caribbean cane fields. In the Americas about II, ০০o or one-quarter of Liberated African arrivals were moved to the British sugar colonies, again largely without having had any input on the decision. But the rest remained in the regions in which they disembarked despite planter hostility and those in Tortola and the Bahamas were able to resist pressures to relocate in Trinidad. ${ }^{55}$ In total the British had some control over the fates of 156,000 of the I $8 \mathrm{I}, 000$ landed recaptives shown in column 3 of Table A.3, yet less than one-third of these $(46,500)$ ever worked in the British Caribbean export sector. If British policy was to get labor for the sugar colonies as some have argued, it was not very successful, in part because many Africans were able to resist. ${ }^{56}$

Villages and subsistence lands in the Freetown hinterland notwithstanding, the great majority of Africans liberated from slave ships were pulled at least partially into the Atlantic wage economy. The people summarized in column 2 of Table A.3 were certainly in this category. 'Working for others' after dispatch to the Caribbean meant abiding by severe vagrancy laws that had no counterpart in any African society. Other recaptives who can be unequivocally identified as working for others - in this case without wages - were the I I,, 00 or so Africans liberated in Brazil, but who were not subsequently relocated to the British Caribbean. Mixed Commission Court emancipados in Cuba who were not removed to British colonies spent years in slave-like conditions, usually on a sugar plantation. Except for a few communities in the Bahamas, all those grouped in the upper half of Table A.3 - those who first disembarked in the Americas in column I and those who moved there in column 2 -became waged laborers. The Cape of Good Hope and Mauritius groups in the second half of the Table should be added to this group and an unknown but large share of Sierra Leone village residents would have entered the waged labor market, sporadically perhaps, for the first time in their lives. There is a vibrant literature on African reconstructions of religion, family, language, and identity in various diasporic environments, but very little on the central issue of African responses to first engagement with an Atlantic labor market. Liberated Africans may be used as a surrogate

54 Table A.3 shows 99,466 recaptives taken into Freetown from which we can subtract I 5, I34 sent to the British West Indies, an estimated I 2,000 pressed into military service (p. 2 I above), and 2,500 who were dispatched to the Gambia as settlers in the 1830 .

55 Adderley, 'New Negroes', 56-9; H. Johnson, 'The Liberated Africans in the Bahamas, I8 I I-60', Immigrants and Minorities, 7:I (1988), I6-40; Dookhan, Virgin Islands, 97-I I9.

56 Schuler, Alas, I-8; Asiegbu, Slavery. Roseanne Adderley argues that British colonial authorities may have had a 'commitment to viewing liberated Africans... as potential plantation laborers'. See her 'New Negroes', 65. 
or sample for the large numbers of enslaved Africans that were not intercepted, but perhaps more important is the range of the terms of labor that they experienced - the 'degrees of freedom' that were possible. Liberated Africans were to be found in every category that historians have defined as falling between full chattel slavery at one end of the spectrum and a wage-free full personal freedom at the other. Historians interested in this topic have almost always first chosen a society in which slavery was abolished and then tried to follow the path of individuals who moved from slave status to some non-slave status in the aftermath of abolition. ${ }^{57}$ The I $8 \mathrm{I}$,, 00 Liberated Africans by contrast offer the prospect of a different approach. These individuals entered just about every slave society in the Americas between I 808 and I 866 - and many lived right through the suppression not only of the slave trade but slavery itself in the Americas.

\section{APPENDIX}

About 172,000 , or 95 per cent, of all post-I 807 recaptives were removed from slave ships by naval vessels charged with suppressing the slave trade. For most of these see STDB, (http://slavevoyages.org/tast/database/search.faces?yearFrom $=\mathrm{I} 808$ \&yearTo $=\mathrm{I} 866 \&$ fate $=$

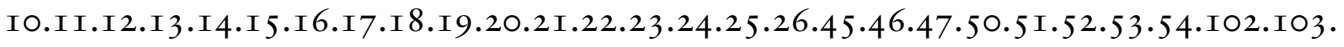
I04.I06.IO8. I09. I IO. I I I. I I 2. I I 3. I I 4. I I 8. I 20. I 2 I. I 22. I 23. I 24. I 25. I 26. I 27.I I28. I 3O. I32.I34.I35.I36.I38.I4I.I42.I44.I48.I49.I 54.I 55.I 56.I 59.I60.I6I.I62.I63.I64.I65. I66.I7I.I72.I73.I74.I76.I77.I78.I79.I80.I8I.I82.I83.I84.I85.I94.I98.201.202.2II), new edition, forthcoming 2014 . The remainder of the 172,000 were on board I 6 vessels that were sailing to São Tomé or Principé at the time of capture, or were picked up on land before embarkation in Africa or after disembarkation in the Americas. For this article we have excluded several hundred recaptives taken by French Caribbean authorities prior to I83 I, a further I,200 carried into the Southern United States between I 807 and I8 I9, and the 15,000 or so taken into custody by the Cuban government after I 835 , all on the assumption that their subsequent lives would have been little different from that of slaves. For Cuban emancipados, see I. R. de Montaud, 'En los borrosos confines de la libertad: el caso de los negros emancipados en Cuba, I8I7-I870', Revista de Indias, 7I:25 I (20I I), I 59-92, which views emancipados as similar to slaves. David Murray stated that 'their fate was mocked by their very name and their tragedy certainly approximated that of Africans who were not liberated from slave ships', in Odious Commerce, 297. Recaptives taken into custody in Brazil on the other hand are included because almost all were kept out of the hands of plantation owners. See D. Williams, The Broken Paths of Freedom: A Spatial History of Free Africans in Nineteenth-Century Brazilian Slave Society (forthcoming). We have also excluded the slaves purchased by the French on the African coast and delivered as 'contract laborers' to Reunion and the French Caribbean between I 848 and I 86 I as well as Dutch purchases of slaves from the Asante for military service in the East Indies. In both cases Africans were eventually liberated after several years of compulsory service

57 F. Cooper, T. C. Holt, and R. J. Scott, Beyond Slavery: Explorations of Race, Labor, and Citizenship in Postemancipation Societies (Chapel Hill, NC, 2000); R. J. Scott and J. M. Hébrard, Freedom Papers: An Atlantic Odyssey in the Age of Emancipation (Cambridge, 2012). 


\begin{tabular}{|c|c|c|c|}
\hline $\begin{array}{l}\text { Nation responsible } \\
\text { for detention }\end{array}$ & $\begin{array}{c}\text { Slave vessels } \\
\text { detained }\end{array}$ & $\begin{array}{l}\text { Africans Embarked } \\
\text { (Number of Vessels) }\end{array}$ & $\begin{array}{l}\text { Africans Disembarked } \\
\text { (Number of Vessels) }\end{array}$ \\
\hline Britain $^{\mathrm{I}}$ & $\mathrm{I}, 596$ & I86,393 (667) & I64,333(667) \\
\hline United States & 68 & $7,289(\mathrm{I} 2)$ & $6,346(\mathrm{I} 2)$ \\
\hline Brazil $^{2}$ & 30 & 5,48 I $(28)$ & $4,878(28)$ \\
\hline Portugal & 57 & $2,383(5)$ & $2,200(5)$ \\
\hline France & $2 \mathrm{I} 4$ & I, $\operatorname{I09}(7)$ & $967(7)$ \\
\hline Argentina & 4 & I,509 (4) & $\mathrm{I}, 437(4)$ \\
\hline Haiti & 3 & $908(3)$ & 808 \\
\hline Spain & 39 & ० & $\circ$ \\
\hline Total & I,994 & $205,072(726)$ & I 80,969 (726) \\
\hline
\end{tabular}

Table A.1: Africans and Vessels Detained in the Atlantic Slave Trade, 1800-67, by Flag of the Capturing Nation (number of vessels with slaves on board). Notes: ${ }^{\mathrm{I}}$ The phrase 'disembarked' includes recaptives who were on board captured slave vessels when the latter arrived at the port of adjudication. It also includes six slave vessels that were shipwrecked on British territory, but for which no legal proceedings have been found, I 6 vessels engaged in the intra-African slave trade to Sao Tome and Ile Principe, and 67 cases of Africans removed from canoes and slave barracoons along the African coast. Neither the intra-African slave traders, nor the in-shore captures, comprising 3,550 recaptives, are included in STDB, (www.slavevoyages.org). ${ }^{2}$ Includes Africans recaptured on land after disembarking from the slave vessel. Source: Liberated Africans spreadsheet available from D. Eltis; B. Mamigonian, 'To be a Liberated African', 280 and 283.

and an argument could be made for including both groups. For the French case, see notes 39 and 40 above, and for the Dutch see most recently G. Austin, J. Baten, and B. Van Leeuwen, 'The biological standard of living in early nineteenth-century West Africa: new anthropometric evidence for northern Ghana and Burkina Faso', Economic History Review, 65:4 (2013), I280-I302. 


\begin{tabular}{|c|c|c|c|c|}
\hline Embarkation Region & \multicolumn{2}{|c|}{ Liberated Africans Landed } & \multicolumn{2}{|c|}{ All Africans Landed from Slave Ships } \\
\hline \multicolumn{5}{|c|}{$1808-1839$} \\
\hline & Slaves & Percentage & Slaves & Percentage \\
\hline Senegambia & $2, \mathrm{I} 40$ & 2.0 & 34,778 & 2.3 \\
\hline Sierra Leone & I3,6 I 5 & I 2.4 & 43,999 & 2.9 \\
\hline Windward Coast & 2,999 & 2.7 & 8,005 & 0.5 \\
\hline Gold Coast & $\mathrm{I}, 5 \mathrm{IO}$ & I.4 & 6,789 & 0.5 \\
\hline Bight of Benin & 33,001 & 30.1 & I 47,745 & 9.8 \\
\hline Bight of Biafra & $39, \mathrm{I} 4 \mathrm{I}$ & $35 \cdot 7$ & I 58,449 & I0.6 \\
\hline W. Central Africa & $\mathrm{I}_{3}, \mathrm{OOI}$ & II. 8 & 885,505 & 59 \\
\hline Southeast Africa & $4, \mathrm{I} 9 \mathrm{I}$ & 3.8 & 215,380 & I 4.4 \\
\hline Total & I09,597 & 100.0 & $I, 500,649$ & IOO \\
\hline \multicolumn{5}{|c|}{$1840-1867$} \\
\hline Embarkation Region & Slaves & Percentage & Slaves & Percentage \\
\hline Senegambia & $29 I$ & 0.4 & 3,653 & I.I \\
\hline Sierra Leone & 2,8 I 5 & 3.9 & I0,67I & $3 \cdot 1$ \\
\hline Windward Coast & I 57 & 0.2 & 500 & O.I \\
\hline Gold Coast & 0 & 0.0 & 507 & O.I \\
\hline Bight of Benin & $\mathrm{I} 7,637$ & $24 \cdot 7$ & 56,730 & I 6.5 \\
\hline Bight of Biafra & $\mathrm{I}, \mathrm{IO5}$ & $\mathrm{I} .4$ & 9,348 & 2.7 \\
\hline W. Central Africa & 44,544 & 62.4 & 224,634 & 65.5 \\
\hline Southeast Africa & $4,9 \mathrm{I} 2$ & 6.9 & 36,802 & 10.7 \\
\hline Total & 71,372 & IOO.० & 342,845 & IOO \\
\hline
\end{tabular}

Table A.2: African Coastal Regions of Embarkation of Liberated Africans Compared to those of all Slaves, two periods, I 808-67. Source: Columns 2 and 3 are derived from the link provided in the Appendix above; columns 3 and 4 are derived from the STDB, (http://slavevoyages.org/tast/assessment/estimates.faces? yearFrom $=\mathrm{I} 808$ \&yearTo=I 866 ), new edition, forthcoming $20 \mathrm{I} 4$. 


\begin{tabular}{|c|c|c|c|}
\hline & & $\begin{array}{l}\text { Arriving after } \\
\text { recapture/shipwreck }\end{array}$ & $\begin{array}{c}\text { Subsequent } \\
\text { movement (net) }\end{array}$ \\
\hline \multicolumn{4}{|l|}{ The Americas } \\
\hline \multirow[t]{13}{*}{ British Caribbean } & Tortola & $2, \mathrm{I} 22$ & -107 \\
\hline & Antigua & $\mathrm{I}, 583$ & Unknown \\
\hline & Dominica & 443 & ० \\
\hline & Barbados & 433 & o \\
\hline & St Vincent & $\circ$ & $+\mathrm{I}, 036$ \\
\hline & St Lucia & ० & +730 \\
\hline & St Kitts/Nevis & ० & +455 \\
\hline & Grenada & $\mathrm{I}, \mathrm{IOO}$ & $+\mathrm{I}, 542$ \\
\hline & Trinidad & I95 & $+8,96 \mathrm{I}$ \\
\hline & Jamaica & 2,950 & $+8,437$ \\
\hline & Bahamas & 6,217 & +900 \\
\hline & British Guiana & 3 I 4 & $+\mathrm{I} 3,746$ \\
\hline & Honduras & 677 & +500 \\
\hline US & US & 6,346 & $-5,500$ \\
\hline $\mathrm{Cuba}^{\mathrm{I}}$ & Havana & I0,799 & $-3,685$ \\
\hline Argentina & Buenos Aires/Patagonia & I,437 & o \\
\hline Haiti & Haiti & $8 \circ 8$ & $\circ$ \\
\hline \multirow[t]{2}{*}{ Brazil } & Bahia & 524 & Unknown \\
\hline & South East Brazil & IO, I I 5 & $-\mathrm{I}, 7 \mathrm{I} 8$ \\
\hline Total & & 46,063 & c. $+25,000$ \\
\hline \multicolumn{4}{|l|}{ Africa and other } \\
\hline \multirow[t]{8}{*}{ Africa } & Senegambia & 967 & $+2,468$ \\
\hline & Sierra Leone ${ }^{\mathrm{I}}$ & 99,466 & $-I_{5}, \mathrm{I} 34$ \\
\hline & Monrovia & o & $+5,500$ \\
\hline & Cape Coast Castle & 45 & 0 \\
\hline & Fernando Po/Gold Coast & $\mathrm{I}, 253$ & Unknown \\
\hline & Lagos & o & $+\mathrm{I}, 500$ \\
\hline & Luanda & 2,200 & $\circ$ \\
\hline & Cape of Good Hope & 5,398 & $+\mathrm{I}, 400$ \\
\hline \multirow[t]{2}{*}{ Other } & St Helena & $24,39 \mathrm{I}$ & $-\mathrm{I} 7,687$ \\
\hline & Mauritius & I, I 86 & $\circ$ \\
\hline Total & & I34,906 & c. $-25,000$ \\
\hline Grand Total & & I80,969 & $\circ$ \\
\hline
\end{tabular}

Table A.3: Regions of Disembarkation of Liberated Africans: Initial Point of Arrival Compared to Ultimate Destinations, I800-67. Note: ${ }^{\text {I }}$ Arrivals in Cuba and Sierra Leone are the number disembarked wherever possible. Such numbers were usually greater than those surviving long enough to be entered in the registers of the Mixed Commission Courts and the British Vice-Admiralty Courts. In the case of Havana, some condemned vessels had disembarked slaves prior to capture and therefore not all those on board became emancipados. Source: Column 4: J. H. Kopytoff, Preface, 6I; Adderley, 'New Negroes', 24 I-8; Asiegbu, Slavery, I 89; Murray, Odious Commerce, 27 I-97; G. W. Roberts and J. Byrne, 'Summary statistics on indenture and associated migration affecting the West Indies, I834-I91 8', Population Studies, 20: I (I966), I25-34. 